\title{
How are Student's Spatial Intelligence for Geometry Problem-Solving?
}

\author{
Yusuf Arkham Prihandika ${ }^{1, *}$ Triyanto $^{2,}$ Dewi Retno Sari Saputro ${ }^{3}$ \\ ${ }^{l}$ Postgraduate of Mathematics Education, Faculty of Teacher Training and Education, Universitas Sebelas Maret \\ Surakarta, Indonesia \\ ${ }^{2}$ Faculty of Teacher Training and Education, Universitas Sebelas Maret Surakarta, Indonesia \\ ${ }^{3}$ Faculty of Mathematics and Natural Sciences, Universitas Sebelas Maret Surakarta, Indonesia \\ *Corresponding author. Email: yusufarkhamp@student.uns.ac.id
}

\begin{abstract}
The purpose of this study was to describe the problem-solving skills students viewed from spatial intelligence. Problemsolving skills are an important component that students must have to solve a problem appropriately. This study is a qualitative study in which the main instrument is the researcher itself. The subject selection technique in this study used purposive sampling. The research data were obtained from the test data description and interview results. Data analysis techniques used in data reduction, data presentation, and conclusion. The validity of the data is obtained through the validation and triangulation method. This study shows that students with high spatial intelligence can identify a given problem, create a plan to solve the problem, and implement a problem-solving plan. Students with intelligence can understand a given problem, make a problem-solving plan, but in implementation. It is still not appropriate. Students with low spatial intelligence cannot identify problems precisely and do not create a completion plan, resulting in not implementing a completion plan.
\end{abstract}

Keywords: Spatial intelligence, Geometry, Problem-solving ability.

\section{INTRODUCTION}

Mathematics is a science that is studied at every level of education [1]. Mathematics can also be a complex science, where there are standards of ability that students need to have in learning mathematics. Problem-solving is one of the standard processes in mathematics learning [2]. This statement implicitly explains that problem-solving skills are an important part of mathematical learning [3]. [4] States that solving mathematical problems is a basic ability that must be embedded in students. Problemsolving skills become an important aspect in students

Table 1. Indicators of problem-solving

\begin{tabular}{|c|c|c|}
\hline No & Indicators & Activities \\
\hline \multirow[t]{3}{*}{1} & \multirow{3}{*}{$\begin{array}{l}\text { Understanding The } \\
\text { Problem }\end{array}$} & Students can identify what is known about the problem. \\
\hline & & Students can identify what to look for. \\
\hline & & Ignored things that were irrelevant to the problem. \\
\hline \multirow[t]{2}{*}{2} & \multirow{2}{*}{$\begin{array}{l}\text { Create a Completion } \\
\text { Plan }\end{array}$} & Students can interpret problems in the form of mathematical symbols. \\
\hline & & Students design problem-solving plans using mathematical formulas. \\
\hline \multirow[t]{2}{*}{3} & \multirow[t]{2}{*}{ Implementing the Plan } & Students begin to solve problems using the way they consider most appropriate. \\
\hline & & Students can do the calculations precisely. \\
\hline 4 & $\begin{array}{l}\text { Summing Up the } \\
\text { Answer }\end{array}$ & Students can interpret the answers obtained. \\
\hline
\end{tabular}


lives, especially in mathematics learning [5]. This ability includes reading and counting through specific procedures [6]. Solving is the ability to get the correct answers to unknown problems and synthesize knowledge from previous experience. [7]. Problem-solving capabilities include the ability to understand problems, draw up plans, execute plans, and the ability to look back [8], [9]. Five stages must be taken in the process of problem-solving, among others reading and thinking, exploring and planning, choosing and strategy, finding answers, and reflecting and extending [10]. Indicators of problem-solving skills include applying problem-solving strategies outside or in mathematics; solve mathematical models and real problems; explain and interrogate the results; identify known, questionable, and adequate elements; create mathematical models [11]. The problemsolving indicator will be presented in table 1 below.

In the process of learning mathematics, there are several aspects learned. One such aspect is geometry. Geometry is a material that has always existed in mathematics because it has become an inseparable entity. Geometry helps to understand every shape in the real world [12]. However, geometry is also a difficult material for students to learn [13]. One of the important abilities in geometric problem solving is spatial intelligence [14] [15] Students have quality spatial-visual intelligence by using their imagination to create creative and innovative thinking skills to solve geometric problems [16]. Spatial intelligence is the ability to mentally organize, understand, and visualize spatial relationships between objects [17]. In addition, spatial intelligence also plays an important role in various aspects, including math problem solving, geometric problem solving, and geometric reasoning [15]. There are five components of spatial intelligence: spatial perception, visualization, mental rotation, spatial relationships, and spatial orientation [18].

Identification needs to be done to find out how the geometry problem-solving capabilities. Teachers will find

\section{METHODS}

\subsection{Design}

This study uses a qualitative research type with a descriptive design. Descriptive research is intended to describe a situation or phenomenon without manipulation or special treatment of a particular object [19]. Qualitative research is exploratory, which can help researchers find out about phenomena that suit the current situation and conditions [20]. Intelligence students. The scope of the study includes spatial intelligence to solve geometry problems.

\subsection{Subjects}

The study used three subjects using high, medium, and low spatial intelligence levels. The subject is selected using purposive sampling techniques. Purposive sampling, also called assessment sampling, is a deliberate selection of samples due to the quality of the subject and chosen not random without the need for the underlying theories or some participants set [21]. The selection of subjects is based on the grades obtained from the student's spatial intelligence test results. The study used averages and standard deviations to categorize students with high, moderate, and low spatial-visual intelligence. The category results are presented in Table 2 below.

In this study, a spatial intelligence test was conducted by testing 69 students then taken subjects with three high categories, three moderate categories, and three low categories but researchers only presented selected subjects who could represent them.

\subsection{Instrument}

The study used geometry problem-solving skills tests

Table 2. Category spatial intelligence

\begin{tabular}{|c|c|c|}
\hline Category & Spatial intelligence scores & Number of students \\
\hline High & $X>57.864$ & 14 \\
\hline Moderate & $30.278<X \leq 57.864$ & 38 \\
\hline Low & $X \leq 30.278$ & 17 \\
\hline \multicolumn{2}{|c|}{ Total } & 69 \\
\hline
\end{tabular}

it easier to know how students understand a geometry concept when they solve geometry problems. The study used spatial intelligence to review students' mistakes.

Identification of problem-solving of student geometry is required as a reference in choosing appropriate learning models and media based on the student's spatial intelligence on geometric materials. Therefore, research is needed to find out how student problem solving is reviewed from spatial intelligence. and structured interviews. The instruments of geometry problem solving and interviews are validated by three experts in mathematics, while four experts in psychology validate spatial intelligence test instruments. The validity used content validity to ensure that the operationalization is relevant to the content to be measured [22]. The math problems will be presented in Figure 1 below. 
oal.

1. Sebuah bak mandi memiliki volume $315.000 \mathrm{~cm}^{3}$ dengan panjang $90 \mathrm{~cm}$ dan tinggi $70 \mathrm{~cm}$. Di atas bak tersebut akan dipasang keran air dengan ketinggian $10 \mathrm{~cm}$ tepat di tengah antara titik $\mathrm{H}$ dan $\mathrm{G}$ dari bak mandi dengan ketentuan bahwa garis $\mathrm{AB}$ berada di bagian depan bawah, kemudian di salah satu sisi bak mandi akan dipasang saluran pembuangan yang berada di tengah antara titik A dan titik B.

a. Tuliskan apa yang di ketahui pada soal tersebut.

b. Ilustrasikan gambar tersebut dengan memberikan nama pada setiap titiknya.

c. Tentukan jarak antara keran dan saluran pembuangan dari bak mandi tersebut jika keduanya saling bersebarangan.

Figure 1 Mathematical Problems

\subsection{Data Collection and Analysis}

The data collection techniques used in this study include spatial intelligence tests, geometry problemsolving tests, and structured interviews. In this study, spatial intelligence tests were used to categorize students' spatial intelligence based on the grades they had obtained, problem-solving geometry tests were used to explore students' problem-solving skills, and interviews were used for data triangulation. Data analysis techniques are used in data reduction, data presentation, and conclusion [23]. Triangulation conducted in this study is triangulation techniques by comparing the test results of students' problem-solving skills and interview results with students. The indicators to be used in this study will be presented in table 1 . Indicators of problem-solving.

\section{RESULTS}

The results showed differences in geometry problemsolving skills between students with high, medium, and low spatial intelligence that will be described as follows.

\subsection{Subject $S-1$}

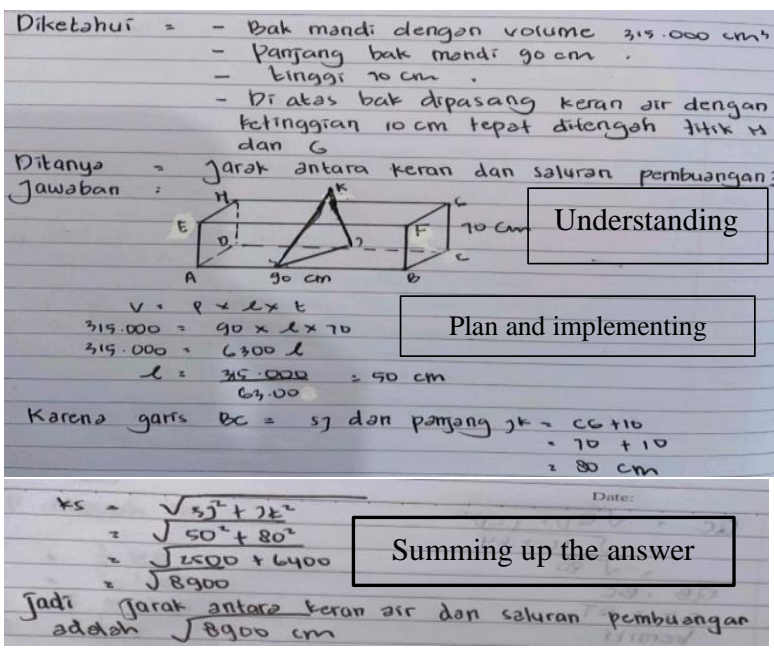

Figure 2 Answer of sheet S-1

Based on figure 2, it is seen that the subject of S-1 can identify the problem of what is known by writing the volume of the bathtub by $315,000 \mathrm{~cm}^{3}$, the length of the bathtub is $90 \mathrm{~cm}$, the height of the bathtub is $70 \mathrm{~cm}$ then writes that above the bathtub is installed a water tap with a height of $10 \mathrm{~cm}$ right between point $\mathrm{H}$ and $\mathrm{G}$. Subject $\mathrm{S}-1$ is also able to identify what to look for and ignore irrelevant information to solve geometric problems. To dig deeper into the understanding of the problem given to the subject of $\mathrm{S} 1$, the researcher presents the following interview excerpt.

$\mathrm{P} \quad$ : Explain what you know about it.

S-1 : It is known that a bathtub has a volume size of $315,000 \mathrm{~cm} 3$, the length of the bathtub is $90 \mathrm{~cm}$, the height of the bathtub is $70 \mathrm{~cm}$. Above the bathtub will be installed a water tap with a height of 10 $\mathrm{cm}$ right in the middle of points $H$ and $G$

$\mathrm{P} \quad$ : What is being asked?

S-1 : Tap distance to disposal.

Furthermore, when viewed from figure 2, the subject of S-1 can also make a plan that is then appropriately implemented. The subject of S-1 makes a plan by writing $V=p x l x t$ and implements the formula correctly. In the answer sheet of subject S-1, it can be known that to determine the distance of the water tap to the sewer, first look for the width of the bathtub. After the bathtub's width is obtained, the subject $\mathrm{S}-1$ continues his work by writing the Pythagorean formula $K S=\sqrt{S J^{2}+J K^{2}}$. Then, do the calculation of the formula that has been written. The subject of the S-1 also involves drawing to make it easier to solve problems by depicting a triangle in the beam image illustration. To dig deeper into the plan and implementation that the subject of S-1 has corrected, the researcher conducts an interview and presents the following excerpts.

$\mathrm{P}:$ Can you create a mathematical model to solve the geometry problem?

S-1 : Yes, you can, sir.

$\mathrm{P} \quad$ : Try explaining the mathematical model you created.

S-1 : I created a volume formula to find width because the width of the bathtub is not yet known.

$\mathrm{P} \quad$ : Which bathtub width means which one?

S-1 : The BC sir

$\mathrm{P} \quad$ : Continue after you get wide from the bathtub. What is the next step?

S-1 : Determine the distance of the tap to the sewer.

$\mathrm{P} \quad$ : How do you do that?

S-1 : It uses the Pythagorean formula.

$\mathrm{P} \quad$ : Which Pythagorean formula?

S-1 : $K S=\sqrt{S J^{2}+J K^{2}}$

$\mathrm{P} \quad:$ How much is SJ?

S-1 : $50 \mathrm{~cm}$ continues his $J K 80 \mathrm{~cm}$

$\mathrm{P}$ : It got from where

S-1 : SJ $50 \mathrm{~cm}$ because $S J=B C$ continues $J K$ it from the height of the bathtub plus the 


\section{height of the faucet from the bathtub is 70 $+10=80$}

From the interview results, it can be known that the subject of S-1 makes a plan that is then implemented precisely through a straightforward calculation process. Subject S-1 explains that the use of volume formulas to determine the width. After determining the width, it can find the distance between the tap to the sewer by using the Pythagorean formula. Then the subject of S-1 also includes a conclusion to end the answer to the problemsolving geometry.

When viewed from the answer sheet and the results of the interview. The subject of S-1 can solve the problem. Even the subject of the $S-1$ creates the image in detail by creating a dotted line on the image.

\subsection{Subject $S-2$}

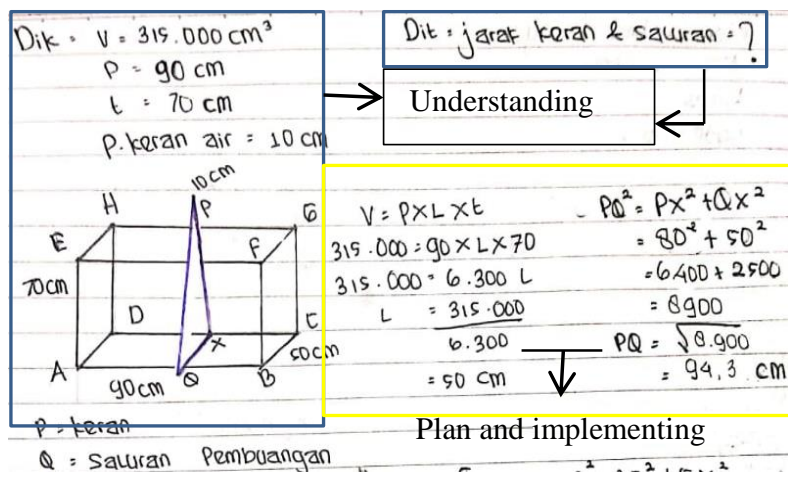

Figure 3 Answer of sheet S-2

Based on figure 3, it appears that the subject of S-2 can identify the problem by writing down important information from the given problem. Subject S-2 writes $\mathrm{v}=315,000 \mathrm{~cm}^{3}, \mathrm{p}=90 \mathrm{~cm}, \mathrm{t}=70 \mathrm{~cm}$. However, there is precise writing where the subject S-2 writes, "P. water tap $=10 \mathrm{~cm}$ " It is certainly not appropriate considering that $10 \mathrm{~cm}$ should be the height of the water tap from the bathtub. The subject of S-2 also writes down a matter of geometry, namely the distance of taps and waterways. It shows a less clear question so that to dig into more indepth information. Researchers conducted interviews on the subject S-2. Here is the interview excerpt.

$\begin{array}{lll}\mathrm{P} & : & \text { What is known about that? } \\ \mathrm{S}-2 & : & \text { Known volume } 315,000 \mathrm{~cm}^{3} \text { tub length } 90 \\ & & \text { cm, height } 70 \mathrm{~cm} \\ \mathrm{P} & : & \text { This is } \mathrm{P} . \text { What does tap mean? } \\ \mathrm{S}-2 & : & \text { Long tap. } \\ \mathrm{P} & : & \text { Is that really what the length of the tap } \\ & & \text { is? } \\ \mathrm{S}-2 & : & \text { Yes, sis. } \\ \mathrm{P} & : & \text { What is being asked about that? } \\ \mathrm{S}-2 & : & \text { Distance of taps and channels. } \\ \mathrm{P} & : \text { What does it mean to distance the taps } \\ & & \text { and sewerage? }\end{array}$

\section{S-2 : The distance between the water tap to the} sewer.

From the interview results, it can be known that the subject of S-2 can understand the problem. However, there is a slight error related to the writing of "P.Tap," which indicates that the subject S-2 does not understand the information of the given problem. The subject of S-2 also writes down what was asked, but on the answer sheet, the subject S-2 is still unclear the intent of the writing. After the interview, it can be known that the purpose of the inscription "Known: Distance of taps and channels" is to determine the distance of water insecurity to the sewerage. From the results of the answer sheet and interview, the subject of S-2 knows what will be determined.

Furthermore, the subject of S-2 can also write a plan that will be used to solve the problem. In the width of the subject answer, S-2 is written $V=p x l x t$ and $P Q^{2}=$ $P X^{2}+Q X^{2}$. Not stopping there, the subject of $\mathrm{S}-2$ also uses the formula to determine the width of the bathtub, which is then implemented to find the distance of the tap to the sewer. The calculations made by the subject $\mathrm{S}-2$ are correct, but there is a slight concept error that is met with the root number $\sqrt{8900}$ Replaced by a decimal number of $94.3 \mathrm{~cm}$. Of course, it violates the concept of the root number. The subject of S-2 also does not conclude solving a geometry problem. To dig deeper into information about plans and implementations, researchers conducted interviews on S-2 subjects. Here is the interview excerpt.

\begin{tabular}{|c|c|c|}
\hline $\mathrm{P}$ & : & Try explaining the formula you made? \\
\hline S-2 & : & $\begin{array}{l}\text { It is a volume formula for looking for } \\
\text { width because the width of the bathtub } \\
\text { is unknown, so it must be searched first. }\end{array}$ \\
\hline $\mathrm{P}$ & : & $\begin{array}{l}\text { Once the width of the bathtub has been } \\
\text { obtained, what is the next step? }\end{array}$ \\
\hline S-2 & : & $\begin{array}{l}\text { Find the distance of the tap to the } \\
\text { sewer. }\end{array}$ \\
\hline $\mathrm{P}$ & : & What formula to find it? \\
\hline$S-2$ & : & Pythagorean formula. \\
\hline $\mathrm{P}$ & : & Which Pythagorean formula? \\
\hline S-2 & : & $P Q^{2}=P X^{2}+Q X^{2}$ \\
\hline $\mathrm{P}$ & : & What is looking for a sloping side? \\
\hline$S-2$ & : & Yes, sir. \\
\hline $\mathrm{P}$ & : & $\begin{array}{l}\text { On your answer sheet, you wrote } \\
\text { that } \sqrt{8900}=94,3 \mathrm{~cm} \text {. Is it like that? }\end{array}$ \\
\hline
\end{tabular}

From the results of interview excerpts, it can be known that the subject of S-2 can make a plan and implement it to solve geometry problems even though as the result, there are errors due to lack of understanding of concepts in mathematics. The concept error was identified when asked, "On your answer sheet, you wrote that $\sqrt{8900}=94,3 \mathrm{~cm}$. Is it like that?" Then the subject of $\mathrm{S}-2$ confirmed the answer. 
When viewed from the answer sheet and the results of the interview. The subject of S-2 has used problem-solving indicators, although some steps are still not appropriate. The images created are also not precise enough to be involved in solving geometric problems.

\subsection{Subject $S-3$}

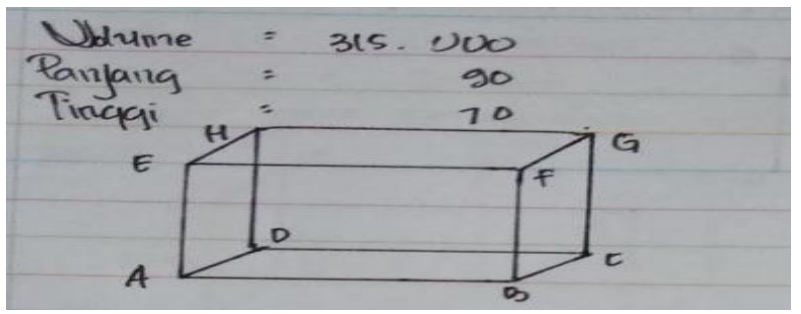

Figure 4 Answer of sheet S-3.

Based on figure 4, it appears that subject S-3 identifies the problem, but only a little information is passed in the answer sheet. The subject of S-3 only writes the volume: 315,000 , then the length: 90 , and the height: 70. Images made by the subject of S-3 also still do not indicate that the subject of S-3 understands the problem of geometry given. The subject of S-3 only draws a beam without any other information or other important information. To deepen the information, the researcher interviewed on the subject of S-3. Here are the interview excerpts.

$\begin{array}{lll}\mathrm{P} & : & \text { What do you know about this? } \\ \mathrm{S}-3 & : & \text { volume } 315,000, \text { length } 90, \text { height } 70 \\ \mathrm{P} & : & \text { Is that all? } \\ \mathrm{S}-3 & : & \text { Yes sir } \\ \mathrm{P} & : & \text { What is being asked about this? } \\ \mathrm{S}-3 & : & \text { Long water tap. } \\ \mathrm{P} & : & \text { Are you sure? } \\ \mathrm{S}-3 & : & \text { That seems to be the case. } \\ \mathrm{P} & : & \text { What makes you doubt? } \\ \mathrm{S}-3 & : & \text { Because I do not understand this. } \\ \mathrm{P} & : \text { Can you create a mathematical formula to } \\ & & \text { solve this problem? } \\ \mathrm{S}-3 & : & \text { Cannot. } \\ \mathrm{P} & : \text { Why can't you create a mathematical } \\ & & \text { formula to solve this problem? } \\ \mathrm{S}-3 & : & \text { Because I do not know how to do it. } \\ \mathrm{P} & : \text { Do you think this problem can be solved? } \\ \mathrm{S}-3 & : \text { Can. } \\ \mathrm{P} & : \text { Do you know the Pythagorean formula? } \\ \mathrm{S}-3 & : \text { I have forgotten. }\end{array}$

From the interview results, it can be known that the subject of S-3 does not understand the given problem. This is indicated when the researcher asks "What is asked in this question?" then the subject of S-3 states that what is asked is the length of the water tap. The subject S-3 is not precise where it should be asked the distance between the water tap and the sewer.
Furthermore, the subject of S-3 also does not make a plan in the form of a formula written on the answer sheet. This certainly raises questions for researchers. Does the subject of S-3 know how to solve a given geometry problem? To dig into more in-depth information, researchers conducted interviews on S-3 subjects. Here is an excerpt of the interview on the subject of S-3.

\begin{tabular}{|c|c|c|}
\hline $\mathrm{P}$ & : & Are you able to solve this problem? \\
\hline S-3 & : & Not \\
\hline $\mathrm{P}$ & : & Why? \\
\hline S-3 & : & I do not know-how \\
\hline $\mathrm{P}$ & $:$ & What does this using formula? \\
\hline S-3 & & Do not know \\
\hline $\mathrm{P}$ & : & $\begin{array}{l}\text { You do not know at all how to solve this } \\
\text { problem? }\end{array}$ \\
\hline-3 & & Yes, I do not know. \\
\hline
\end{tabular}

From the results of the interview, it can be known that the subject of S-3 can not work on geometry problems. When asked, "Are you able to solve this problem?" the subject of S-3 explained that he did not know how to solve the geometry problem. Then when asked the formula that will approximately be used to solve a given geometry problem, the subject S-3 states that he does not know. From this, researchers have an idea that the subject of S3 can solve that is still lacking.

When viewed from the answer sheet and the results of the interview. The subject of S-3 writes down what is known but the information written is still very minimal. After the interview, it turned out that the subject of S-3 also still did not understand the problem given. Then the subject of S-3 is also unable to solve the problem of geometry. This is evidenced by the width of the answer that does not write formulas or do calculations to solve the geometry problem that has been given.

\section{DISCUSSIONS}

Based on the results of the description of the data that has been presented, it can be known that each subject has different levels of spatial intelligence has different geometric problem-solving abilities as well. Each subject writes down the completion steps, although the subjects S-1, S-2, and S-3 have different steps.. Subjects S-1, S-2, and $\mathrm{S}-3$ make a beam-shaped construction of information obtained to illustrate the problem then involves the image to solve the geometry problem. The subject of S-1 tends to describe a geometric problem solving into visual form well where every detail in the image is noticed, such as creating a dotted line that indicates that it is a line inside the beam. Spatial intelligence helps students to convert accepted material into writing or images. The subject of the S-2 also creates an image but still lacks detail because it should be made a separate line to indicate that the line is behind the side of the beam. For the subject S-3 also makes a beam but the information written is still very minimal. Students with high spatial intelligence have 
better problem-solving skills than students with moderate and low intelligence, whereas students with moderate spatial intelligence have better math skills than students with low spatial intelligence [15].

From the interviews conducted by researchers to the subject S-2, ignorance of the concept of encouraging to make mistakes can be known. Problem-solving activities relate to the student experience [24] so that the things taught by the teacher are very important in the problemsolving process. Spatial intelligence correlates with students' problem-solving abilities [25]. Students with low spatial intelligence cannot deform problems into geometric shapes. This is because transformation and skills are common mistakes students make due to the incomprehension of choosing the procedures to be used in problem-solving [26]. Students with low spatial intelligence tend to make more mistakes, including transformation, encoding, and process skills [27]. The following is an excerpt of an interview that researchers conducted on the subject S-3.

From the interview results, it can be known that the subject S-3 can not answer the problem given because of the difficulty to identify what to look for, so that the following process is deadlocked.

\section{CONCLUSION}

Based on the discussion that has been presented, researchers concluded that all students solve geometry problems by constructing images. However, high spatial intelligence students tend to solve geometry problems by making more detailed image construction. Students with moderate spatial intelligence are constructing images, but the form of images that have been made is still not appropriate, which does not include the erased line behind the side of the beam. Students with low spatial intelligence try to solve geometry problems by constructing images but the information written is still not enough to represent the given problem. In the completion step, students with high spatial intelligence also make a plan that is then implemented to solve geometry problems, and calculations are done without difficulty. Students with moderate spatial alignment can also write a research plan, but the implementation is still not appropriate. Students with spatial intelligence are committing to such a problem caused by the misconceptions experienced. Students with low spatial intelligence could only write down a small amount of information given to the problem. Students with low spatial intelligence could also not solve geometry problems, not even knowing the plan to solve them. The results of this study can be used as a reference in subsequent research on the ability to solve geometric problems with different types of problems, such as HOTS or PISA like problems.

\section{ACKNOWLEDGMENTS}

Researchers thanked the students of SMA N 1 Pulokulon who had participated in the data collection in this study.

\section{REFERENCES}

[1] R. W. Utami and D. U. Wutsqa, "Analisis kemampuan pemecahan masalah matematika dan self-efficacy siswa SMP Negeri di Kabupaten Ciamis," J. Ris. Pendidik. Mat., vol. 4, no. 2, pp. 166-175, 2017.

[2] NCTM, "Principle and Standards for School Mathematics," J. Equine Vet. Sci., vol. 18, no. 11, pp. 1-6, 2000.

[3] A. L. Son and S. Fatimah, "Students ' Mathematical Problem-Solving Ability Based," Journal on Mathematics Education., vol. 11, no. 2, pp. 209222, 2020.

[4] H. Hendriana, E. Eti Rohaeti, and W. Hidayat, "Metaphorical thinking learning and junior high school teachers' mathematical questioning ability," J. Math. Educ., vol. 8, no. 1, pp. 55-64, 2017.

[5] C. M. Pertiwi, E. E. Rohaeti, and W. Hidayat, "The Students' Mathematical Problem-Solving Abilities, Self-Regulated Learning, and Vba Microsoft Word in New Normal: a Development of Teaching Materials," Infin. J., vol. 10, no. 1, pp. 17-30, 2020.

[6] M. Z. Mardhiah, M. Mailizar, and E. Elizar, "Students' mathematics problem-solving skills in PISA problems," AIP Conf. Proc., vol. 2331, pp. 18, 2021 .

[7] E. Juliyanto, K. Kunci, P. Inkuiri, B. Proyek, and K M. Masalah, "Model Pembelajaran Ipa Dengan Pendekatan Inkuiri Berbasis Proyek Untuk Menumbuhkan Kompetensi Menyelesaikan Masalah," Indones. J. Sci. Educ., vol. 1, no. 1, pp. 36-42, 2017.

[8] Depdiknas, "Peraturan Menteri nomor 22 Tahun 2006 1," 2006, pp. 1-43.

[9] G. Polya, How to solve it, Princeton University Press, 1957.

[10] S. Krulik and J. A. Rudnick, Problem Solving: A Handbook for Elementary School Teachers, Temple University, 1988.

[11] W. Hidayat and R. Sariningsih, "Kemampuan Pemecahan Masalah Matematis Dan Adversity Quotient Siswa SMP Melalui Pembelajaran Open Ended," J. Nas. Pendidik. Mat., vol. 2, no. 1, pp. 109-118, 2018.

[12] B. Cantürk-Günhan, M. Turgut, and S. Yilmaz, "Spatial ability of a mathematics teacher: The case of Oya," IBSU Sci. J., vol. 3, no. 1, pp. 151-158, 2009. 
[13] K. M. A. Fauzi, I. W. Dirgeyase, and A. Priyatno, "Building Learning Path of Mathematical Creative Thinking of Junior Students on Geometry Topics by Implementing Metacognitive Approach," Int. Educ. Stud., vol. 12, no. 2, pp. 57-66, 2019.

[14] U. Hanifah, D. Juniata, and T. Y. E. Siswono, "Students' Spatial Performance: Cognitive Style and Sex Differences," J. Phys. Conf. Ser., vol. 947, no. 1, pp. 1-7, 2018.

[15] A. Kurniawan, M. T. Budiarto, and R. Sulaiman, "Student's spatial ability of junior high school in solving geometric problems based on mathematical ability," AIP Conf. Proc., vol. 2014, pp. 1-9, 2018.

[16] Ambarwati, T. B. Setyawan, and E. Yudianto, "Analisis Kemampuan Visual Spasial Siswa Dalam Menyelesaikan Soal Matematika Berstandar PISA Konten Shape And Space Ditinjau Dari Level Berpikir Geometri Van Hiele," Kadikma., vol. 09, no. 03, pp. 51-60, 2018.

[17] N. Lee and S. Park, "Stereoscopic Visualization for Improving Student Spatial Skills in Construction Engineering and Management Education," 122nd ASEE Annual Conference \& Exposition., pp. 1-11, 2015.

[18] P. H. Maier, "Spatial Geometry And Spatial Ability - How To Make Solid Geometry Solid?," 1996 Annu. Conf. Didat. Math., pp. 69-81, 1998.

[19] L. N. Pradana, O. H. Sholikhah, S. Maharani, and M. N. Khalid, "Virtual mathematics kits (VMK): Connecting digital media to mathematical literacy," Int. J. Emerg. Technol. Learn., vol. 15, no. 3, pp. 234-241, 2020.

[20] M. Irfan, B. Kusumaningrum, Y. Yulia, and S. A. Widodo, "Challenges During the Pandemic: Use of E-Learning in Mathematics Learning in Higher Education," Infin. J., vol. 9, no. 2, pp. 147-158, 2020.

[21] I. Etikan, S. A. Musa, and R. S. Alkassim, "Comparison of Convenience Sampling and Purposive Sampling," Am. J. Theor. Appl. Stat., vol. 5, no. 1, pp. 1-4, 2016.

[22] V. K. Shrotryia and U. Dhanda, "Content Validity of Assessment Instrument for Employee Engagement," SAGE Open., vol. 9, no. 1, pp. 1-7, 2019.

[23] Sugiyono, Metode Penelitian Kuantitatif, Kualitatif dan R\&D, Alfabeta, 2017.

[24] Abdul Rahman and Ansari Saleh Ahmad, "Exploration of mathematics problem-solving process based on the thinking level of students in junior high school," Int. J. Environ. Sci. Educ., vol. 11, no. 14, pp. 7278-7285, 2016.

[25] F. Rahbarnia, S. Hamedan, and F. Radmehr, "A study on the relationship between multiple intelligences and mathematical problem solving based on revised bloom taxonomy," J. Interdiscip. Math., vol. 17, no. 2, pp. 109-134, 2014.

[26] K. Fadhilah Zamzam and F. Alfiana Patricia, "Error Analysis of Newman to Solve the Geometry Problem in Terms of Cognitive Style," vol. 160, no. Incomed 2017, pp. 24-27, 2018.

[27] N. Riastuti, M. Mardiyana, and I. Pramudya, "Students' Errors in Geometry Viewed from Spatial Intelligence," J. Phys. Conf. Ser., vol. 895, no. 1, pp. $1-6,2017$. 